\title{
Title: Management challenges at film-induced tourism heritage attractions
}

\author{
Justyna Bakiewicz, Edinburgh Napier University \\ Anna Leask, Edinburgh Napier University \\ Paul Barron, Edinburgh Napier University \\ Tijana Rakic, University of Brighton
}

\begin{abstract}
In response to an increasingly competitive environment, a number of heritage visitor attractions (HVAs) have encouraged filming, as well as subsequent film-induced tourism, in order to raise their profile, generate revenue and differentiate themselves from other attractions. However, while film-induced tourism may bring benefits, it can also be problematic, especially at HVAs which have conservation at their core. This paper identifies a variety of challenges that film-induced tourism has created at Rosslyn Chapel and Alnwick Castle, both UK-based HVAs popular among filminduced tourists. The findings show that film-induced tourism resulted in a number of challenges at both sites not solely related to an increase in visitor numbers but also changes in visitor profile and behavior. Film-induced tourism at both sites has not only influenced visitors' expectations but also preferences for heritage interpretation resulting in management tensions. This paper concludes with a discussion of possible heritage management responses to these challenges.
\end{abstract}

\section{Keywords}

Management challenges, film-induced tourism, heritage visitor attractions, Alnwick Castle, Rosslyn Chapel 


\section{Introduction}

Heritage Visitor Attractions (HVAs) encompass a variety of natural, architectural, social, cultural and educational resources (Connell, Page \& Meyer, 2015) and play a significant part not only in the conservation process (Leask, 2008) but also in the engagement of visitors with a destination (Connell, et al. 2015; Leask, 2010). However, the philosophies, missions and products available at each HVA differ significantly from one another due to the individual nature of their resources (Leask, 2008; Leask, Fyall \& Garrod, 2013b). Their role and purpose vary depending upon the destination's context, ownership, stakeholders and level of revenue streams (Leask, 2008).

HVAs, and especially built heritage sites, are difficult to manage as visitors to those sites, instead of consuming physical products, consume an experience (Alexander, Bryce \& Murdy, 2016). This experience, along with visitors' own prior knowledge and exposure to these sites across a variety of sources, including popular media products such as films, informs the meanings that visitors attach to these places. Therefore, HVAs are also a multifaceted social constructs (Chronis, 2008) and are "privileged objects of tourist pilgrimages" (Mazierska \& Walton, 2006, p. 5), where visitors can, somewhat similar to television and film viewers (Davin, 2005), travel backwards in time (Mazierska \& Walton, 2006), and, in the case of film tourists, explore the blurred boundaries between history and fiction. Importantly, in the context of film-induced tourism at HVAs, existing management complexities might be further exacerbated by the popularization of a site through its exposure in popular media products. 
A rich body of knowledge on film-induced tourism has been produced over the past three decades and this knowledge production has drawn on a wide range of disciplines and fields of studies (e.g. see Beeton, 2001, 2005, 2010; Busby \& Klug 2001; Buchmann, More \& Fisher 2010; Connell, 2005, 2012; Connell \& Meyer, 2009; Croy \& Buchmann, 2009; Hudson \& Ritchie, 2006; Kim, 2012; Macionis, 2004; Macionis \& Spark, 2009; Riley, Baker \& Van Doren, 1998; Rittichainuwa \& Rattanaphinanchai, 2015; Tooke \& Baker, 1998; Carl Kindon \& Smith, 2007; Couldry \& McCarthy, 2004; Hao \& Ryan, 2013; Jewell \& McKinnon, 2008; Martin-Jones 2014; Zimmermann, 2007). Despite the richness of, and interest in, film-induced tourism from scholars approaching the topic through a variety of different (inter)disciplinary lenses, a number of themes remain under-researched. Key amongst these is the theme of HVA management challenges within the context of film-induced tourism. Namely, although management challenges at HVAs have been explored by a number of scholars (e.g. see Carter \& Grimwade, 1997; Darlow, Essex \& Brayshay 2012; Fyall \& Garrod, 1998; Fyall \& Rakić, 2006; Garrod Fyall Leask \& Reid, 2012; Irimiás, 2014; Leask, 2010; Nicholas \& Thapa, 2013), there is a lack of research which has explicitly explored management challenges HVAs face as a consequence of film-induced tourism.

This article therefore aims to address this gap and explore the complex relationship between heritage management and film-induced tourism, with a particular focus on management challenges at two built HVAs that were further popularized through their representation in media products. The article commences with an overview of management challenges at HVAs in general, including the complex relationship between tourism and heritage management, revenue generation, and visitor access, as well as conservation and issues of heritage interpretation. The debate then moves 
onto the discussion of film-induced tourism at HVAs, followed by an overview of the methodological approach and methods, and a discussion of the key findings in relation to management challenges at Rosslyn Chapel and Alnwick Castle. The article concludes with a discussion surrounding the implications of the findings for film-induced tourism related heritage management practices.

\section{Literature Review}

\section{The complex relationship between tourism and heritage management}

The increasing recognition of the need to adopt a more commercial outlook in the management of HVAs has resulted in a number of concerns in many UK and international HVAs. Namely, not only face external and internal operating issues, but also have to deal with a number of heritage management challenges specific to the sector (Garrod \& Fyall, 2000; Leask Fyall \& Garrod, 2013b). A close relationship between tourism and heritage is one of the complexities of management at various international HVAs. Such a complex relation may result in a wide range of concerns such as exploitation of facilities rather than the preservation and conservation of heritage sites (Ahmad 2013; Garrod \& Fyall, 2000; Ho \& McKercher, 2004; Wang \& Bramwell, 2012). Differing stakeholders' views may be one of the factors leading to the conflict (Aas Ladkin \& Fletcher, 2005; Imran, Alam \& Beaumont, 2014; Leask, 2010; Wilkes \& Richards, 2008).

A further complexity lies in the fundamental differences between developmental aims of tourism and heritage preservation (Zhang, Fyall \& Zheng, 2015). However, although tourism development raises heritage management concerns, it can also be seen as an important justification of, and basis for, the preservation of heritage resources (Hall, 2001; Prideaux \& Kininmont, 1999; Fyall \& Rakić, 2006; Rakić, 2008; Wang \& Bramwell, 2012; Zhang et al., 2015). Managers' lack of understanding 
of this relationship between tourism and heritage, in instances in which this occurs, can represent a significant problem in that heritage managers might not realize that there is a need to both protect the actual heritage site and operate as a visitor attraction (Croft, 1994; Darlow et al., 2012). In order to avoid conflicts and achieve balance, the relationship between tourism, heritage conservation and stakeholders should be based on maturity, knowledge and willingness to support heritage resources (Wang \& Bramwell, 2012).

\section{Revenue generation and the commercial imperative}

Over the last two decades, HVAs have been facing a decrease in public funding whilst concurrently dealing with the ever-increasing variety and number of emerging commercial leisure attractions competing in the market (Leighton, 2007; Leask et al., 2013b). Thus, the competitive, diverse and often over-supplied marketplace in which HVAs operate, combined with a decrease in public funding, has forced HVA managers to become increasingly open to exploring alternative revenue streams, including dynamic pricing strategies, retail and catering services, on and off site events, and entertainment activities (Leask, 2008; Leighton, 2007; Leask et al., 2013b). Therefore, finding additional, and commercially beneficial, ways to engage visitors through diverse and innovative, rather than traditional products has also become a significant aspect of the heritage management agenda (Leask, 2010; Leask, Barron \& Fyall, 2013a; Taheri, Jafari \& O'Gorman, 2014).

Such activities, while increasing revenue streams, have been regarded somewhat negatively by some managers of HVAs (Garrod, Leask \& Fyall, 2007; Leask, 2008). This is because some of the possible visitor-oriented approaches and commercial activities may not always be appropriate, or might in some cases clash with existing conservation and preservation strategies (Leighton, 2007). This reluctance to 
commercialize HVA operations originates from the concept that heritage sites differ significantly from general visitor attractions in their aims, objectives, management practices and approaches. Therefore, the application of revenue management systems at such sites can be challenging (Garrod \& Fyall, 2000; Leask et al., 2002).

\section{Visitor access, conservation and protection of resources}

Finding the balance between visitor access, conservation and the protection of resources is an additional ongoing dilemma that managers of HVAs need to face (Carter \& Grimwade, 1997; Leask, 2010; Li Wu \& Cai, 2008; Timothy \& Boyd, 2003), a dilemma which often includes a concern about commodification (Bunten 2008; Fyall \& Rakić, 2006; Halewood \& Hannam, 2001; Ho \& McKercher, 2004). As a means of protecting conservation, some managers restrict access to heritage resources where excess visitor numbers may result in overcrowding or cause damage (Austin, 2002; Mason, 2005; Santana-Jiménez \& Hernández, 2011). Indeed, some managers at HVAs with a strictly curatorial imperative consider themselves more as guardians of heritage, rather than providers of access to heritage, consequently concluding that "public access is not a prominent part of management consideration" (Garrod \& Fyall, 2000, p. 684). This has been found to be a more common concern at religious sites, where visitor access might need to be limited because of the impact it might cause (Olsen, 2006; Shackley, 2009; Yeh Aliana \& Zhang, 2012; Wong, Mclntosh \& Ryan, 2016).

The dangers associated with increasing visitor numbers and the focus on preservation has created a conservative approach to the management of HVAs. This, in turn, has resulted in a lack of willingness by some managers to embrace change and take into account a site's contemporary purpose (Grimwade \& Carter, 2000; Smith 1999; Timothy \& Boyd, 2006) along with visitors' changing, diversifying 
expectations and demographics (Leask et al., 2013a; Massara \& Severino, 2013; Sheng \& Chen, 2012). Carter and Grimwade (1997) argue that restricting access provides only a temporary solution to the issue of access and conservation. The challenge lies not in the restriction of visitor access but in maintaining HVA accessibility in a manner that sustains and protects their significance and, where appropriate, enhances their value (Negi, 2012). That said, many HVAs were not originally built to accommodate large volumes of visitors (Garrod, 2008). As a result, during the peak tourist season overcrowding and overuse of resources (Pegg, Patterson \& Gariddo, 2012) can occur. However, overcrowding is brought into sharp relief when one considers the significant seasonal fluctuations experienced by many HVAs, which results in significant visitor numbers during the peak tourist season and the overuse of resources and their partial, or even complete, shutdown in the low season (Connell et al., 2015).

\section{Interpretation at HVAs}

Heritage interpretation, although an integral part of management at HVAs, also poses a number of challenges (Chen \& Chen, 2010; Daengbuppha Hemmington \& Wilkes, 2006; Hughes Bond \& Ballantyne, 2013; Moscardo \& Ballantyne, 2008; Poria Biran \& Reichel, 2009). Managing HVAs of multiple use, to which a variety of different meanings are usually attached by visitors (Ashworth, 2009) is one of the key challenges for heritage interpretation (Bell, 2012; Poria et al., 2009). Managers of such sites need to balance different values as well as differing priorities and interests and, at the same time, fulfill their visitors' needs and expectations (Bell, 2012). The variety of meanings and prior expectations that different visitors ascribe to HVAs may also, to some extent, affect their preferences and use of interpretation methods. This could, in turn, inform management decisions on what messages they 
should convey (Austin, 2002; Herbert, 2001; Poria et al., 2009). However, the interpretation at HVAs often concentrates on one perspective and is based on a monolithic narrative (Poria et al., 2009). Thus, given the multifaceted nature of HVAs and the tensions between preservation and tourism, issues relating to revenue generation, seasonality and interpretation can come to the fore. Managers of HVAs need to become more aware of the wide variety of challenges that they may face, including the multitude of meanings visitors attach to HVAs and their changing expectations which, as this article will demonstrate, are highlighted in situations where HVAs are further popularized through film and media products.

\section{Film-induced tourism and heritage visitor attractions (HVAs)}

Media products, such as films, have increasingly determined the way heritage is being reproduced, marketed and sold, with a particularly selective set of messages being conveyed (Caton \& Santos, 2007). According to Dann (1994), visual images that are employed to advertise, represent and construct heritage experiences are related to cultural symbols and used to promote an uncomplicated past, which is more closely related to entertainment and leisure than to the history of that particular HVA. A selective approach to the past and preferences for particular interpretations are being practised in order to make heritage more attractive for contemporary consumption (Lowenthal, 1985).

Film-induced tourism can be seen as a dimension of pop culture tourism (Gyimóthy, Lundberg, Lindström, Lexhagen \& Larson, 2015; Larson, Lundberg \& Lexhagen, 2013) and, in the cases where a film induces visitation to a heritage site, it can also be regarded as a form of heritage tourism (Hoppen, Brown \& Fyall, 2014; MartinJones, 2014). This is mainly because popular media, together with the postmodern lifestyle and the increased use of the internet, new technologies and a variety of 
different media types, makes the past and heritage omnipresent and widely accessible for people's consumption (Butler 2011; Månsson, 2011). The combination of these factors has resulted in the popularity of a number of HVAs increasing as a consequence of being featured in different films.

Winter (2002, p. 335), for example, revealed an important issue based on a case study of Angkor and its representation in Tomb Raider, stating that the problem lies in the "the contradiction between ideas of heritage as an imaginary vision of Angkor's management and the reduction of Angkor to a culturally and historically disembedded spectacle". Schofield (1996), on the other hand, in his research regarding alternative heritage tourism in Manchester and its cinematographic images, demonstrated how media products, such as films, can inspire new form of tourism to emerge. Frost (2006), in contrast, examined the historic film Ned Kelly and its impact on heritage tourism in north-eastern Victoria. Issues explored included the recognition of the importance of historic films in the development of heritage tourism, balanced with the requirement for maintaining the authenticity of sites. Pan and Ryan (2011) conducted research in Hong Kong on Wing Lee Street, the setting of an award-winning film Echoes of the Rainbow, which demonstrated how media shaped the agenda in terms of conservation, as well as the process by which the film created a heightened awareness of the heritage values of this location in Hong Kong.

Management challenges at HVAs are, thus, often created as a result of allowing visitor access to heritage resources in the first place and these challenges can then be further exacerbated by a dramatic increase in visitor numbers, which can, at some HVAs, be the consequence of film-induced tourism. Simultaneously, however, a deeper understanding of visitor experience and expectations at HVAs popular among film-induced tourists is likely to assist in the development of appropriate 
tourism products, interpretation methods and management strategies, which will contribute to protecting the heritage resources and also engage a wide range of visitors. This research therefore aims to contribute to knowledge through the development of a deeper understanding of the complex relationship between heritage management and film-induced tourism. Specifically, this study aims to identify tensions between preservation and tourism at two HVAs popular among filminduced tourists and thus identify management challenges brought about by the impact of film induced tourism.

\section{Research Methodology}

While heritage management and interpretation studies have, in the main, relied on quantitative or mixed methods (e.g. see Beeho \& Prentice, 1997; Moscardo, 1996; Poria et al., 2009), qualitative approaches are increasingly being seen as both useful and necessary in the context of research projects which either incorporate a focus on the complexities of visitors' experiences (Ryan, 2000) or happen to be interdisciplinary heritage management studies (Connell \& Lowe, 1997). In addition to addressing the gap in the existing literature, this study with its qualitative approach, further contributes to methodological plurality within heritage management studies.

Underpinned by a constructivist paradigm, the primary research was conducted by the lead author in July and August 2013 and incorporated a range of qualitative methods, ranging from semi-structured face-to-face interviews with managers, guides and visitors at Rosslyn Chapel and Alnwick Castle, to observation sessions. These two sites were particularly suitable as both were (built) HVAs which have experienced the phenomenon of film-induced tourism. In addition, these were also represented in media products in two different ways. Rosslyn Chapel, a working church, is mentioned as a real place associated with The Da Vinci Code book and 
film, whereas Alnwick Castle, home to the Percy family, served as a backdrop for the two first Harry Potter films, where it played a fictional role as Hogwarts.

The sites were motivated to be involved in film-induced tourism for different reasons, with Alnwick Castle primarily looking to develop new products to attract new audiences and generate increased visitor income, while Rosslyn Chapel was more motivated by the opportunity to raise funds for ongoing conservation work and a desire to maintain the authentic representation of the site in the film. The choice of two significantly different HVAs allowed for the identification and better understanding of various heritage management challenges and issues linked to filminduced tourism at HVAs in general.

Based on theoretical sampling, at Rosslyn Chapel interviews were conducted with a Director, two managers (the Interpretation Manager and the Visitor Services Manager), and four guides. At Alnwick Castle, interviews were conducted with the Director, three managers (the Marketing Manager, the Interpretation Manager, and the Visitor Services Manager), and three guides. These particular participants (managers and guides) were purposively selected due to their knowledge of the sites, heritage management, and interpretation issues, as well as their professional experience of working at HVAs. The selection of participants for interviews with visitors, which focused on their experiences and preferences for heritage interpretation, was based on convenience sampling. The interviews with visitors were conducted over a three-week period, during July and August 2013, on the grounds of Rosslyn Chapel and Alnwick Castle and were conducted at different times of the day in order to gain the broadest range of data by interviewing different types of visitors. Altogether, twenty-three interviews, with both domestic and international visitors, were conducted at Rosslyn Chapel and thirty at Alnwick Castle. 
All interviews were audio recorded and conducted in a conversational style. Although pre-designed themes were used as a guide for these semi-structured interviews, the interviews were very flexible in that questions were not asked in any particular order and allowed for significant flexibility. This created a relaxed environment, encouraging interviewees to go into greater detail about the issues under investigation, and allowed the lead author to receive "verbal accounts of social realities" (Fox, Edwards \& Wilkes, 2010, p. 76).

Interview transcripts were analyzed using an inductively-conducted thematic analysis, within which the themes emerged from the actual data. The lead author looked for patterns, themes and categories - constantly moving backwards and forwards between the entire data set, while simultaneously discussing the emerging themes with the co-authors. This was supported through noting ideas and coding schemes throughout the process of analysis (see also Braun \& Clarke, 2006), as well as reflection on the essential themes (Hayllar \& Griffin, 2005). The final stages of collaborative writing represented a continuation of analysis and involved, as can be seen in the discussion of findings below, also some contextualization of data (Denzin, 1989 cited in Hayllar \& Griffin, 2005).

\section{Findings and Discussion}

Management at both HVAs recognized the importance of tourism as a means of contributing to and supporting their valuable heritage product. Both HVAs made a conscious decision to become involved in filming, as they believed that this might generate additional revenue for conservation purposes and the overall improvement of the sites. Given that both the Da Vinci Code and the Harry Potter franchise were exceptionally popular, management at both sites could have predicted significant impacts from subsequent film-induced tourism. The findings discussed below explore 
the management challenges brought about by the film-induced tourism and the methods with which the management of both HVAs responded to these.

\section{An increase in visitor numbers}

Both Rosslyn Chapel and Alnwick Castle experienced a significant increase in visitor numbers immediately after their exposure in media products caused them to become recognisable as film locations. Before its inclusion in The Da Vinci Code Rosslyn Chapel was a relatively unknown heritage site with approximately 30,000 visitors a year (Rosslyn Chapel Trust 2015). After the book was published, visitor numbers increased to 140,000 per year and then to 176,000 in the year of the film's release (ibid.). This exposure made Rosslyn Chapel a popular heritage visitor attraction not only from a regional and national perspective, but also on an international basis. Similarly, since Alnwick Castle's exposure in the Harry Potter films, visitor numbers increased significantly from 60,000 in 2001 to 300,000 in 2003 (Director of Alnwick Castle 2013).

The increase in visitor numbers at Rosslyn Chapel was first triggered by the publication of The Da Vinci Code book, due to the naming of the Chapel in the original text. The release of the film further increased the interest in the Chapel and this had a subsequent impact on visitor numbers. The experience at Alnwick Castle was different to that of Rosslyn Chapel, as the Harry Potter books did not influence visitor numbers and it was only after the first film's release - together with a marketing campaign that made the connection with Alnwick Castle, highlighting that the Castle served as Hogwarts School of Witchcraft and Wizardry - that visitor numbers rose. Thus, whilst both HVAs experienced film-induced tourism, one 
(Rosslyn Chapel) played an integral element in the story, whilst the other (Alnwick Castle) was used merely as a backdrop.

Visitor numbers at both sites reduced a few years after the films' initial release, although they remain much higher than before the films and data shows that Roslyn Chapel currently receives 160,255 visitors a year (Rosslyn Chapel Trust, 2015). Visitor numbers at Alnwick Castle have also decreased from 300,000 to 250,000 , although in 2014 visitor numbers increased again up to 280,000 and current visitor numbers are approximately 294,000 (Alnwick Castle Management, Personal Communication). Such an increase might be a result of a combination of the final Harry Potter release, and the recent TV series, Downton Abbey, which was also filmed at the Castle, and the development of a new exhibition based on this popular TV series at the site.

According to the Director of Alnwick Castle, even though the Castle featured in only the first two Harry Potter films, visitor volume increased again slightly with the release of each subsequent Harry Potter film. This enduring effect at Alnwick Castle was also related to the development of new interpretation methods, which reinforced the connection between the Harry Potter films and the site. However, such an overt connection to The Da Vinci Code was not made at Rosslyn Chapel, and visitor numbers nonetheless remain high. The management at Alnwick Castle made a conscious decision to undertake a significant marketing campaign to make and maintain the connection with the Harry Potter films, making people aware of the connection and, thus, boosting tourism at the site. Rosslyn Chapel, on the other hand, did not have to employ any marketing tools, as the book itself, and then the film, raised people's awareness of the site. 
At Rosslyn Chapel film-induced tourism created significant seasonality patterns, and subsequent management challenges, with very high visitor numbers during the summer months and low numbers during the winter months. Alnwick Castle, where the larger site may mean that higher numbers of visitors are easier to manage, does not experience such seasonality patterns. It also operates as a visitor attraction for only seven months of the year. Although Rosslyn Chapel is open all year round, the high season at the site lasts four to five months with significant overcrowding problems during the months of July and August.

A key issue at Rosslyn Chapel was overcrowding which led to exceeded carrying capacity and put pressure on fragile resources. The lack of management techniques for handling increased visitor numbers and consequent issues, such as overcrowding, has been emphasized in the literature on heritage management (Cochrane \& Tapper, 2008; Garrod et al., 2008; Shackley, 1999). Overcrowding at Rosslyn Chapel also affected the site's atmosphere and visitors' experiences. For example, many visitors commented that they did not expect to see so many other people or did not expect the Chapel would become so popular among film-induced tourists. Some suggested that the site lost its meaning(s) due to the high number of visitors. This relationship between overcrowding and visitors' experience often most visible at religious HVAs and less apparent at other HVAs (Leask \& Yeoman, 1999; Shackley 2009), was also noted by a number of authors (e.g. see du Cros, 2008; Fyall \& Garrod, 1998; Yeh et al., 2012). This is consistent with findings contained in this paper, as overcrowding - and its impact on visitors' experience of the atmosphere and sense of place - was recognized almost exclusively at Rosslyn Chapel, which is a working church.

\section{Changes in visitor profile}


Following their exposure in film, both HVAs experienced changes in visitor profile which in turn created specific management challenges. In both cases, such changes were perceived as mainly positive, as the films encouraged a wide range of domestic and international visitors and created a new type of visitor who would not normally be interested in visiting heritage sites. This phenomenon is discussed in the filminduced tourism literature, within which some studies highlight the risk that a film may encourage mainly film-induced tourists, replacing traditional visitors, and that this change may not necessarily be socially acceptable at sites of historic value (Beeton, 2001, 2004). A similar phenomenon was seen at Rosslyn Chapel and Alnwick Castle, where, for example some visitors, who might not otherwise be drawn to regularly visit heritage sites had been specifically attracted to visit as a consequence of the films. It was found that these visitors, did not necessarily always appreciate these HVAs as sites with historic value and significance, and often associated the site primarily, or wholly, with the films.

However, this change in visitor profile highlights the fact that some film-induced tourists may not necessarily take into account or consider the fact that they are visiting a valuable historic site with fragile, irreplaceable resources and, and it was found that, on some occasions, might behave in an inappropriate manner. This kind of behavior was more evident at Rosslyn Chapel, where visitors would behave in a manner that demonstrated little respect for the Chapel as a working church. This indicates that there seems to be a significant difference between religious and nonreligious sites, and reinforces the existing view that inappropriate visitor behavior and tourism activities are most challenging at religious sites (Leask \& Yeoman, 1999; Shackley, 2009). This change in visitor profile then, presents a range of challenges that demand management to recognize the expansion of visitor types, understand 
that certain groups of visitors may have little or no interest in, or experience of, visiting HVAs, and that specific challenges occur in sites of religious value.

\section{Impact of film related expectations on heritage interpretation}

This study has not only confirmed existing claims that film-induced tourism may influence visitors' expectations of a place (e.g. see Beeton, 2005; Connell, 2009 2012; Kim, 2012), but has also taken the discussion further by exploring film-induced tourism's impact on heritage interpretation and its influence on visitor expectations. Indeed, as highlighted by managers and guides at both sites, one of the key heritage interpretation challenges is related to visitors' expectations resulting from media exposure. For example, when asked about challenges of heritage interpretation, the Director of Rosslyn Chapel commented:

I think part of it [the Chapel's representation in The Da Vinci Code] I would say is expectation, which may not be right. Partially in terms of the story is a book of fiction, is a story, and some people don't see it necessarily as a story. (Director of Rosslyn Chapel, July, 2013)

Interviews with visitors at both sites confirmed that their expectations were, in some cases, derived from The Da Vinci Code at Rosslyn Chapel and the Harry Potter films at Alnwick Castle. The quotes in the following paragraph from visitor interviews include a number of references either to the book or film, demonstrating that they created a number of new, and sometimes unrealistic, expectations in the visitors' minds which, as highlighted by managers, become to some extent problematic for heritage interpretation management. For example, some visitors to Alnwick Castle believed that they would see the interior of Hogwarts inside Alnwick Castle, when, in fact, Alnwick Castle's interiors were never used in any of the scenes featuring the 
interior of Hogwarts. Indeed the Marketing Manager at Alnwick Castle commented on this particular issue, saying that:

If it is not explained to people that the Castle was only used for exterior filming, people may come in to the Castle and expect it. I have heard a visitor saying, "I came in and expected to see the Great Hall from Hogwarts" and, of course, that wasn't here, that was in a studio. So I think some people, when they go inside, are surprised that it doesn't look like Hogwarts on the inside but it's difficult to manage those expectations. (Marketing Manager at Alnwick Castle, August, 2013)

When talking to visitors, it became apparent that although most of them did not necessarily seek, or expect to see, Harry Potter images inside the state rooms, there were some visitors who, as mentioned by the director, believed the state rooms would resemble Hogwarts. Indeed, despite knowing that Alnwick Castle was one of many locations that served as Hogwarts, Benjamin and his son Ezra still enthusiastically anticipated seeing the interior of the Castle, expecting to see Hogwarts. 
Benjamin (mid-forties, from Israel): Actually there are some scenes from the movie that I expect to see still inside [...] hopefully we will get to see some of the rooms, some of the settings for the movie, but it is also the beauty of the Castle regardless of the movie.

Ezra (early-twenties, from Israel): In the movie you don't get to see that much of the outside of the Castle, there is more inside.

Benjamin: I think some of the movies were actually not filmed here, they were filmed in other places. Before the kids walk inside they can't know which part of the movie was filmed here.

Ezra: I think when we go inside it will be easier to recognize it.

In the case of Rosslyn Chapel, both The Da Vinci Code book and the film described the Chapel as a very peaceful and quiet place. Some of the typical comments from the visitors include those of Joan and Maria (see below), both of whom refer to their pre-visit imagination of the site in this light.

Joan (mid-forties, from the USA): I thought there would be fewer people, I kind of assumed that it would be a smaller one-to-one tour. I didn't expect to walk in and have probably a hundred people sitting there. 
Maria (early fifties, from Venezuela): Well, I knew it was a Chapel so I assumed it would be quite small, but I didn't think there would be so many people here. Even though I knew it was a tourist place, tourist attraction, I didn't expect to see so many people [...] I don't know why [...] It could be that I was influenced by the film and imagined it would be very peaceful here. I think that it somehow loses its meaning because of that.

Other visitors were negatively surprised by the presence of the new visitor center, through which visitors now need to go in order to reach the actual Chapel:

David (mid-fifties, from Shetland): The visitor centre is a slight distraction for me [...] I would have preferred to come here through that little gate over there. I would have preferred the place as it was before The Da Vinci Code. It is a pity that it is not the same anymore. It is a pity that you can't go through that little gate instead of through the visitor centre.

Entering the Chapel through a modern building does not match the pre-visitation imagination of many, especially given that the description in the book and the aerial shot of Rosslyn Chapel seen in the film does not mention nor depict anything similar to the contemporary construction currently attached to the Chapel.

\section{Balancing management tensions and visitor expectations}

The impact of the films on visitor expectations was recognized by management at both HVAs to be a significant management challenge. As the representation of Rosslyn Chapel and Alnwick Castle influenced visitors' expectations, this resulted in changes to heritage interpretation. For example, since Rosslyn Chapel featured in 
The Da Vinci Code and visitor numbers increased significantly the guided tours were shortened by 20 minutes, which, according to guides, affected the visitor experience. However, in recognition of visitors' expectations, guides at Rosslyn Chapel also started incorporating elements of The Da Vinci Code in their talks, as exemplified in the quote below:

During the tour I always talk about The Da Vinci Code and I talk about how they went about filming the place [...] Very often what I'm trying to do is to give a little bit of something for everyone, and that of course includes talking about The Da Vinci Code because it's the main thing that brought people here recently in the last few years. There is no getting away from that fact, we know that from the visitor numbers and I enjoy talking about that because it brings a smile to people's faces. They [visitors] recognise it and say "Yeah, The Da Vinci Code, of course!" (Tom, guide at Rosslyn Chapel, July, 2013)

A similar situation was evident at Alnwick Castle where the Harry Potter films and their consequent influence on visitors' expectations affected the historical guided tour, which was initially based exclusively on the history of the Castle. After the site's exposure in Harry Potter, visitors on the historical guided tours were said to be more interested in learning about the 'magical' narratives of the Castle, derived from the Harry Potter films, rather than the historical narratives. Thus, historical guides were, to some extent, forced to embed the fictional elements of Harry Potter into the historical guided tours. Ela, an Alnwick Castle guide, stated that: 
I've started adding bits of Harry Potter because a lot of people who come still do want to know about it, so that's why I like mentioning where they filmed. I try to talk about two famous Harrys, Harry Hotspur and Harry Potter and try to mix it for fun. When people come, as much as they might want to know about the history, they also want to have fun. That's why I'm trying to talk about it. (Ela, historical guide at Alnwick Castle, August, 2013)

Indeed, according to the Heritage Interpretation Manager at Alnwick Castle, existing heritage interpretation had to be expanded and modified to include Harry Potter in the overall offering; otherwise, the site would have very quickly lost visitors who visit due to the Harry Potter connection. The Interpretation Manager commented:

I think if Alnwick hadn't changed what it gave to the visitors' overall offer, then I think visitors would have gone... Visitors, you know, they are quite picky about what they do. (Interpretation Manager, August, 2013)

Consequently, elements of Harry Potter have been incorporated into the historical overview of the castle and Harry Potter has now become an integral part of the 'stories' about the Castle. This inclusion has been formalised and a range of other forms of interpretation have been developed by management that are inspired by the Harry Potter films, such as Potter-inspired characters, the Battleaxe to Broomstick Tour, and broomstick training. In addition, the management have refocused the brochures describing Alnwick Castle, from the original image of the historical Harry Hotspur to take advantage of the Harry Potter characters (see Figure 1). The use of Alnwick Castle in the Harry Potter films was also included in the 
overall historical timeline, which is presented on the main wall of the exterior of the Castle.

\section{[Please insert Figure 1 here]}

The representation of both sites in media products, and the subsequent changes made to heritage interpretation, created management challenges related to commodification. For example, managers at Rosslyn Chapel, although aware of visitors' expectations derived from media exposure, faced a significant dilemma as to whether such an association with The Da Vinci Code should be made in the overall heritage interpretation. Given that the Chapel is a church and a significant heritage site, they decided to keep information related to The Da Vinci Code to a minimum, as they were concerned that larger volume of this content might inappropriately diminish the overall historical significance of the Chapel and could lead to its commodification. Simultaneously, both the management and the guides were not aiming to devalue ideas derived from the film or the book, but rather to show the visitors that Rosslyn Chapel is more than a movie set.

Therefore, achieving a balance between historical and fictional narratives while at the same time meeting visitors' expectations has become a major management concern at Alnwick Castle. Indeed, the marketing manager stated that one of the most challenging issues is to satisfy visitors' various expectations and achieve a balance between the history of the Castle and the new Harry Potter related meaning(s) of the Castle. Resultantly, the managers at Alnwick Castle developed interpretation based on the fictional world of Harry Potter, rather than solely on the Castle's history. However, the managers had a difficulty in achieving the ideal balance so as not to overshadow the site's historical significance, while meeting visitors' diverse expectations. Furthermore, there was also a risk that the traditional 
visitors, interested in the site's history, might become alienated and possibly also replaced by an audience predominantly seeking the fictional connections of the site with the films.

\section{Conclusion and Implications}

This article addressed issues relating to the under-researched area of heritage management challenges at HVAs popular among film-induced tourists. The findings demonstrate a significant shift in terms of management aims and objectives, from traditional, based mainly on conservation and education, to more contemporary, which include a consideration of visitors' expectations and experiences. In addition, the findings also support some of the previous studies, suggesting that there is still a lack of understanding among managers of HVAs of the various types of impact that film-induced tourism may have. However, as this article has demonstrated, when

effectively managed, film-induced tourism at HVAs can create opportunities for revenue generation through the development of new tourism products, marketing activities, and heritage interpretation methods and thus contribute to the preservation of heritage resources.

One of the challenges associated with film-induced tourism at HVAs, as far as these two sites were concerned, was related to a long-term increase in visitor numbers, with the influx placing sudden and unpredictable pressure on the resources available. In common with other HVAs that have been involved in filming activity onsite, the sites found there to be a surge in visitor numbers immediately following the release of films, without sufficient time to predict and plan appropriate mechanisms to maintain the integrity of the site features and visitor experience. However, tensions caused in the initial post-release stage tend to be resolved once the sites 
developed clearer understanding of their new visitor profile and interests, allowing them to develop appropriate management solutions that have enhanced the additional revenue generation opportunities alongside provision of relevant interpretation and resource management tools.

As this article has argued, there are also differences, in this case between a site used as a backdrop and a site that formed an integral part of a film's story. Although based on insights from two HVAs, these findings nonetheless have significant implications, in terms of film choice, for managers who aspire for their HVA to feature in a film. As shown in this article, when an HVA serves solely as a backdrop for a fictional location it may require additional funds for marketing activities to reinforce the connection between the site and the film.

Although the change in visitor profile was another challenge identified at both HVAs included in this study, it affected Rosslyn Chapel more, most likely due to the fact that unlike Alnwick Castle, Rosslyn Chapel is a working church. Therefore some visitor behaviors were perceived as problematic by the management, thus emphasizing once again the individual nature of HVAs and the need for techniques and tools appropriate to each site.

Interestingly, while this article reinforced arguments made in the literature relating to the fact that film-induced tourism influences visitors' expectations (Beeton, 2005; Connell, 2012; Kim, 2012), it also revealed the significant impact of film-induced tourism on visitors' preferences for heritage interpretation available on site, with a number of visitors at both sites looking for interpretation associated with the films. In responding to the film-induced tourism phenomenon, as well as film-induced tourists' expectations, managers at both Rosslyn Chapel and Alnwick Castle used 
interpretation as their main management technique. Consequently however, achieving a balance between the historical and fictional content relating to the films, and at the same time meeting visitors' expectations, became a major management concern. In other words, film-induced tourists' expectations for media related content within interpretation inevitably created a tension between the meanings attached to the history of these HVAs and the contemporary media-induced meaning(s) resulting from their exposure in these films and books. Thus, a clear challenge of managing HVAs that have featured in popular media products is to balance film tourists' expectations, derived from films and other media products, with the authenticity of the sites, in a consistent and planned manner that is relevant to the site's resources and visitors.

Managers at both sites have developed a number of strategies in response to the film-induced tourism related challenges resulting from the sites' exposure in media products. The main strategy after the exposure of Rosslyn Chapel and Alnwick Castle in media products, and the consequent issues and challenges resulting from film-induced tourism activities, was via the use of heritage interpretation. That said, the two sites employed slightly different approaches. Rosslyn Chapel kept the interpretation based on The $\mathrm{Da}$ Vinci Code to a minimum, and managers also developed additional heritage interpretation methods unrelated to the book or the film. Alnwick Castle, on the other hand, developed additional interpretation specifically inspired by the Harry Potter films. In addition, the Castle has also strengthened the historical narratives by the employment of heritage interpretation based solely on the history of the Castle. Some of the strategies employed by the managers at both sites were the same, for example, both sites improved the existing facilities and interpretation methods, as well as using heritage interpretation as a 
management tool to manage issues related to high visitor numbers. Interestingly, both sites also used guided tours as a tool to manage visitor expectations and provide enriched experiences for visitors, whilst maintaining the integrity of the site. This article has contributed to the identification and increased understanding of heritage management challenges at HVAs popular among film tourists. The findings at Rosslyn Chapel and Alnwick Castle provided an insight into interpretation challenges as well as highlighted the value of heritage interpretation as a management tool which can be of central importance in further improving visitor experiences at HVAs that have become popular film locations. That said, while the some of the management techniques discussed in this article are likely to prove valuable for other HVAs at which film-induced tourism takes place, prior to adapting some of these techniques, managers of other HVAs popular among film-induced tourists would ideally first need take into account the individual nature of their site, including its original purpose, current use, stakeholders and the resources available. Incorporating media product related narratives within heritage interpretation, although valuable in some cases, may not always be appropriate especially in cases in which the site's stakeholders might perceive this as overshadowing the site's historical value and meaning. In some cases, interpretation based on media products will need to be kept to minimum and new interpretation methods based on historical or other narratives relevant to the site might need to be developed. Therefore enhancing income opportunities and enriching visitors experience whilst maintaining the integrity of the site should be made imperative for HVA management.

While this research was based at two UK-based HVAs, film-induced tourism is an international phenomenon that is increasingly forming part of the motivations for visitors to destinations. The very individual nature of HVAs means that the findings 
are specific to these individual circumstances, although it should be noted that many of the challenges and aspects discussed will relate directly to a broad range of HVAs internationally.

With these complexities in mind, future research could explore the modes in which visitors' preferences for particular types of interpretation, as well as for varied balance between historical and media related content at HVAs might be influenced by the type of the HVA in question and its context. Such studies would further current understanding of visitors' engagement with heritage interpretation at HVAs popular among film tourists and, in turn, also contribute towards further improvements within HVA management practice. 


\section{References}

Aas, C., Ladkin, A., and Fletcher, J. (2005). "Stakeholder collaboration and heritage management." Annals of Tourism Research, 32(1), 28-48.

Ahmad, A. (2013). "The constraints of tourism development for a cultural heritage destination: The case of Kampong Ayer (Water Village) in Brunei Darussalam." Tourism Management Perspectives, 8, 106-113.

Alexander, M., D. Bryce, and S. Murdy. (2016). "Delivering the Past: Providing Personalized Ancestral Tourism Experiences". Journal of Travel Research, 113.

Andriotis, K. 2011. "Genres of heritage authenticity: Denotations from a Pilgrimage landscape." Annals of Tourism Research, 38(4),1613-1633.

Austin, N. K. 2002. "Managing heritage attractions: Marketing challenges at sensitive historical sites." International Journal of Tourism Research, 4(6), 447-457.

Ashworth, G. 2009. Let's sell our heritage to tourists! Do we? Can we? Should we? [online]. In J. Carlsen, M. Hughes, K. Holmes, and R. Jones (eds.), CAUTHE 2009: See Change: Tourism and Hospitality in a Dynamic World. Fremantle, W.A.: Curtin University of Technology. Available at: http://search.informit.com.au/documentSummary;dn=167008303001267;res=I ELBUS [accessed 30.09.2015].

Beeho, A. J. and Prentice, R. C. 1997. "Conceptualizing the experiences of heritage tourists. A case study of New Lanark World Heritage Village." Tourism Management, 18(2), 75-88. 
Beeton, S. 2001. "Smiling for the camera: The influence of film audience on a budget tourism destination." Tourism, Culture and Communication, 3, 15-25.

Beeton, S. 2005. "Film-induced tourism". Clevedon; Buffalo: Channel View Publications.

Beeton, S. 2010. "The advance of film tourism." Tourism and Hospitality Planning and Development, 7(1), 1-6.

Bell, V. R. 2012. "The politics of managing a World Heritage Site: The complex case of Hadrian's Wall." Leisure Studies, 4, 1-18.

Berger, P. L., and Luckmann, T. 1966. "The social construction of reality: A treatise in the sociology of knowledge." Garden City, N.Y: Doubleday.

Braun, V., and Clarke, V. 2006. Using thematic analysis in psychology. Qualitative Research in Psychology, 3(2), 77-101.

Buchmann, A., Moore, K., and Fisher, D. 2010. "Experiencing film tourism. Authenticity and fellowship." Annals of Tourism Research, 37(1), 229-248.

Busby, G., and Klug, J. 2001. "Movie-induced tourism: The challenge of measurement and other issues." Journal of Vacation Marketing, 7(4), 316332.

Butler, R. 2011. "It's only make believe: The implications of fictional and authentic locations in films." Worldwide Hospitality and Tourism Themes, 3(2), 91-101.

Carl, D., Kindon, S. and Smith, K. 2007. "Tourists' experiences of film locations: New Zealand as 'Middle-Earth'." Tourism Geographies, 9(1), 49-63. 
Carter, B., and Grimwade, G. 1997. "Balancing use and preservation in cultural heritage management." International Journal of Heritage Studies, 3(1), 45-53.

Caton, K., and Santos, C. 2007. "Heritage tourism on Route 66: Deconstructing nostalgia." Journal of Travel Research, 45(4), 371-386.

Chen, C. F., and Chen, F. S. 2010. "Experience quality, perceived value, satisfaction and behavioral intentions for heritage tourists." Tourism Management, 31(1), 29-35.

Chronis, A. 2008. "Co-constructing the narrative experience: Staging and consuming the American Civil War at Gettysburg." Journal of Marketing Management, $24(1), 5-27$

Connell, J. 2005. "Toddlers, tourism and Tobermory: Destination marketing issues and television-induced tourism." Tourism Management, 26(5), 763.

Connell, J. 2012. "Film tourism: Evolution, progress and prospects." Tourism Management, 33(5), 1007-1029.

Connell, J., and Lowe, A. 1997. "Generating grounded theory from qualitative data: The application of inductive methods in tourism and hospitality management research." Progress in Tourism and Hospitality Research, 3(2), 165-174.

Connell, J., and Meyer, D. 2009. "Balamory revisited: An evaluation of the screen tourism destination-tourist nexus." Tourism Management, 30(2), 194-207.

Connell, J., Page, S. J., and Meyer, D. 2015. "Visitor attractions and events: Responding to seasonality." Tourism Management, 46, 283-298.

Cochrane, J., and Tapper, R. 2008. Tourism's contribution to World Heritage Site management. In A. Leask and A. Fyall (eds.), Managing World Heritage Sites (pp. 97-107). Oxford: Butterworth-Heinemann. 
Couldry, N. 1998. The view from inside the 'simulacrum': Visitors' tales from the set of Coronation Street. Leisure Studies, 17(2), 94-107.

Couldry, N., and McCarthy, A. 2004. Orientations: Mapping Mediaspace. In N. Couldry and A. McCarthy (eds.), Mediaspace: Place, scale and culture in a media age (pp. 1-18). London: Routledge.

Croft, T. 1994. What price access? Visitor impact on heritage in trust. In J. M. Fladmark (ed.), Cultural Tourism (pp. 169-178). London: Donhead Publishing.

Croy, W. G., and Buchmann, A. 2009. Film-induced tourism in the High Country: Recreation and tourism contest. Tourism Review International, 13(2), 147155.

Cuccia, T., and Rizzo, I. 2011. Tourism seasonality in cultural destinations: Empirical evidence from Sicily. Tourism Management, 32, 3, 589-595.

Daengbuppha, J., Hemmington, N., and Wilkes, K. 2006. Using grounded theory to model visitor experiences at heritage sites: Methodological and practical issues. Qualitative Market Research: An International Journal, 9(4), 367-388.

Dann, G. 1994. Tourism: The nostalgia industry of the future. In W. F. Theobald (ed.), Global Tourism: The Next Decade (pp. 55-67). Oxford: ButterworthHeinemann Ltd.

Darlow, S., Essex, S., and Brayshay, M. 2012. Sustainable heritage management practices at visited heritage sites in Devon and Cornwall. Journal of Heritage Tourism, (3), 1-19.

Davin, S. 2005. Tourists and television viewers: Some similarities. In Crouch D. and J. D. Thomson (eds.), The Media and the Tourist Imagination. Converging Cultures (pp. 170-182). London: Routledge. 
Denzin, N. K. 2001. The reflexive interview and a performative social science. Qualitative Research, 1(1), 23-46.

Denzin, N. K. 1989. Interpretive interactionism. Newbury Park, Calif.: Sage Publications.

du Cros, H. 2008. Too much of a good thing? Visitor congestion management issues for popular World Heritage tourist attractions. Journal of Heritage Tourism, 2(3), 225-238.

Fox, D., Edwards, J., and Wilkes, K. 2010. Employing the Grand Tour approach to aid understanding of garden visiting. In G. Richards and W. Munsters (eds.), Cultural Tourism Research Methods (pp. 75- 87). Wallingford, Oxfordshire, UK, CAB International.

Frost, W. 2006. Braveheart-ed Ned Kelly: Historic films, heritage tourism and destination image. Tourism Management, 27(2), 247-254.

Fyall, A., and Garrod, B. 1998. Heritage tourism: At what price? Managing Leisure, 3(4), 213-228

Fyall, A. and Rakić 2006. The future market for world heritage sites. In A. Leask and A. Fyall (eds.), Managing World Heritage Sites (pp. 159-175). Oxford: Butterworth-Heinemann.

Garden, M. C. E. 2006. The Heritagescape: Looking at landscapes of the past. International Journal of Heritage Studies, 12(5), 394-411.

Garrod, B. 2009. Managing visitor impact. In A. Fyall, B. Garrod, and A. Leask (eds.), Managing Visitor Attractions: New Directions (pp. 125-139). Oxford, Butterworth-Heinemann.

Garrod, B., and Fyall, A. 2000. Managing heritage tourism. Annals of Tourism Research, 27(3), 682-708. 
Garrod, B., Fyall, A., Leask, A., and Reid, E. 2012. Engaging residents as stakeholders of the visitor attraction. Tourism Management, 33(5), 1159-1173.

Garrod, B., Leask, A., and Fyall, A. 2007. An assessment of 'international best practice' in visitor attraction management: Does Scotland really lag behind? International Journal of Tourism Research, 9(1), 21-42.

Gyimóthy, S., Lundberg, C., Lindström, K. N., Lexhagen, M., and Larson, M. 2015. Popculture tourism research manifesto. In D. Chambers and T. Rakić (eds.), Tourism Research Frontiers: Beyond the Boundaries of Knowledge (pp. 13-26). Elsevier. Emerald Group Publishing.

Goulding, C., and Domic, D. 2009. Heritage, identity and ideological manipulation: The case of Croatia. Annals of Tourism Research, 36(1), 85-102.

Grimwade, G., and Carter, B. 2000. Managing small heritage sites with interpretation and community involvement. International Journal of Heritage Studies, 6(1), 33-48.

Guba, E. G. 1990. The alternative paradigm dialog. In E. G. Guba (ed.), The Paradigm Dialog (pp. 17-30). London: Sage Publications.

Halewood, C., and Hannam, K. 2001. Viking heritage tourism. Annals of Tourism Research, 28(3), 565-580.

Hall, C. 2001. World heritage and tourism. Tourism Recreational Research, 26(1), 13.

Hao, X., and Ryan, C. 2013. Interpretation, film language and tourist destinations: A case study of Hibiscus Town, China. Annals of Tourism Research, 42(2), 334358.

Harrison, R. 2013. Heritage: Critical approaches. Milton Park, Abingdon; New York: Routledge. 
Herbert, D. 2001. Literary places, tourism and the heritage experience. Annals of Tourism Research, 28(2), 312-333.

Ho, P., and McKercher, B. 2004. Managing heritage resources as tourism products. Asia Pacific Journal of Tourism Research, 9(3), 255-266.

Hoppen, A., Brown, L., and Fyall, A. 2014. Literary tourism: Opportunities and challenges for the marketing and branding of destinations? Journal of Destination Marketing and Management, 3(1), 37-47.

Hudson, S., and Ritchie, J. 2006. Promoting Destinations via Film Tourism: An Empirical Identification of Supporting Marketing Initiatives. Journal of Travel Research, 44(4), 387-396.

Hubbard, P., and Lilley, K. 2000. Selling the past: Heritage-tourism and place identity in Stratford-upon-Avon. Geography, 85(3), 221-232.

Hughes, K., Bond, N., and Ballantyne, R. 2013. Designing and managing interpretive experiences at religious sites: Visitors' perceptions of Canterbury Cathedral. Tourism Management, 36, 210-220.

Hayllar, B., and Griffin, T. 2005. The precinct experience: A phenomenological approach. Tourism Management, 26(4), 517-528.

Imran, S., Alam, K., and Beaumont, N. 2014. Environmental orientations and environmental behaviour: Perceptions of protected area tourism stakeholders. Tourism Management, 40, 290-299.

Irimiás, A. 2014. The Great War heritage site management in Trentino, northern Italy. Journal of Heritage Tourism, 9(4), 317-331.

Jamal, T., and Hollinshead, K. 2001. Tourism and the forbidden zone: The underserved power of qualitative inquiry. Tourism Management, 22(1), 63-82. 
Jewell, B., and McKinnon, S. 2008. Movie tourism: A new form of cultural landscape? Journal of Travel and Tourism Marketing, 24(2-3), 153-162.

Kim, S. 2012. Audience involvement and film tourism experiences: Emotional places, emotional experiences. Tourism Management, 33(2), 387-396.

Larson, M., Lundberg, C., and Lexhagen, M. 2013. Thirsting for vampire tourism: Developing pop culture destinations. Journal of Destination Marketing and Management, 2(2), 74-84.

Leask, A. 2008. Nature and purpose of visitor attractions. In A. Fyall, B. Garrod, A. Leask and A. Leask (eds.), Managing Visitor Attractions (2nd ed.) (pp. 5-15). Oxford: Elsevier.

Leask, A. 2010. Progress in visitor attraction research: Towards more effective management. Tourism Management, 31(2), 155-166.

Leask, A., Barron, P., and Fyall, A. 2013a. Generation Y: Opportunity or challenge strategies to engage generation $\mathrm{Y}$ in the UK attractions' sector. Current Issues in Tourism, 16(1), 17-46.

Leask, A., Fyall, A., and Garrod, B. 2013b. Managing revenue in Scottish visitor attractions. Current Issues in Tourism, 16(3), 240-265.

Leask, A., and Yeoman, I. 1999. Heritage Visitor Attractions: An Operations Management Perspective. London; New York, N.Y.: Cassell.

Leighton, D. 2007. Step back in time and live the legend: Experiential marketing and the heritage sector. NVSM International Journal of Nonprofit and Voluntary Sector Marketing, 12(2), 117-125.

Li, M., Wu, B., and Cai, L. 2008. Tourism development of World Heritage Sites in China: A geographic perspective. Tourism Management, 29(2), 308-319. 
Lowenthal, D. 1985. The Past is a Foreign Country. Cambridge, New York: Cambridge University Press.

Macionis, N. 2004. Understanding the film-induced tourist. In Frost, W, Croy, G and Beeton, S (eds.). International Tourism and Media Conference Proceedings. 24th-26th November 2004. Melbourne: Tourism Research Unit, Monash University. 86-97.

Macionis, N., and Sparks, B. 2009. Film-induced tourism: An incidental experience. Tourism Review International, 13(2), 93-102.

Månsson, M. 2011. Mediatized tourism. Annals of Tourism Research, 38(4), 16341652.

Mason, P. 2005. Visitor management in protected areas: from 'hard' to 'soft' approaches. Current Issues in Tourism, 8(2\&3), 181-194.

Massara, F., and Severino, F. 2013. Psychological distance in the heritage experience. Annals of Tourism Research, 42, 108-129.

Mazierska, E., and Walton, J. 2006. Tourism and the moving image. Tourist Studies, $6(1), 5-11$.

Martin-Jones, D. 2014. Film tourism as heritage tourism: Scotland, diaspora and The Da Vinci Code (2006). New Review of Film and Television Studies, 12(2), 156-177.

McKercher, B., Ho, P. S. Y., and du Cros, H. 2005. Relationship between tourism and cultural heritage management: Evidence from Hong Kong. Tourism Management, 26(4), 539. 
Moscardo, G. 1996. Mindful visitors: Heritage and tourism. Annals of Tourism Research, 23(2), 376-397.

Moscardo, G., and Ballantyne, R. 2008. Interpretation and attractions. In A. Leask, B. Garrod, S. Wanhill and A. Fyall (eds.), Managing Visitor Attractions: New Directions. (pp. 237-252) Oxford: Butterworth-Heinemann.

Negi, A. 2012. Accessibility at World Heritage sites: An inclusive approach. Svayam [online]. Available at: www.svayam.com [accessed: 13.09.2015].

Nicholas, L., and Thapa, B. 2013. The politics of world heritage: A case study of the Pitons management area, St Lucia. Journal of Heritage Tourism, 8(1), 37-48.

Nuryanti, W. 1996. Heritage and postmodern tourism. Annals of Tourism Research, 23(2), 249-260.

Nyaupane, G. 2009. Heritage complexity and tourism: The case of Lumbini, Nepal. Journal of Heritage Tourism, 4(2), 157-172.

Olsen, D. H. 2006. Management issues for religious heritage attractions. In D. J. Timothy and D. H. Olsen (eds.), Tourism, Religion and Spiritual Journey (pp. 104-118). London: Routledge.

ORNC. 2012. The Old Naval College hits the big screen [online]. Available at: http://www.ornc.org/index.php/press/story/the-old-royal-naval-college-hits-thebig-screen [accessed 10.09.2012].

Pan, S., and Ryan, C. 2011. Film-induced heritage site conservation: The case of echoes of the rainbow. Journal of Hospitality and Tourism Research, 37(1), 125-150. 
Pegg, S., Patterson, I., and Gariddo, P. V. 2012. The impact of seasonality on tourism and hospitality operations in the alpine region of New South Wales, Australia. HM International Journal of Hospitality Management, 31(3), 659666.

Prideaux, B., and Kininmont, L.J. 1999. "Tourism and Heritage Are Not Strangers: A Study of Opportunities for Rural Heritage Museums to Maximize Tourism Visitation". Journal of Travel Research, 37 (3), 299-303.

Poria, Y., Biran, A., and Reichel, A. 2009. Visitors' preferences for interpretation at heritage sites. Journal of Travel Research, 48(1), 92-105.

Rakić, T. 2008. (PhD Thesis) World Heritage, Tourism and National Identity: A Case Study of the Acropolis in Athens, Greece. Edinburgh Napier University.

Ritchie, J., and Lewis, J. 2003. Qualitative Research Practice: A Guide for Social Science Students and Researchers. London; Thousand Oaks, Calif.: Sage Publications.

Riley, R., Baker, D., and Van Doren, C. S. V. 1998. Movie-induced tourism. Annals of Tourism Research, 25(4), 919-935.

Rittichainuwat, B., and Rattanaphinanchai, S. 2015. Applying a mixed method of quantitative and qualitative design in explaining the travel motivation of film tourists in visiting a film-shooting destination. Tourism Management, 46, 136147.

Roslyn Chapel Trust 2015. Consolidated Report and Financial Statements for the Year Ended 31 March 2015.

Ryan, C. 2000. Tourist experiences, phenomenographic analysis, post-postivism and neural network software. International Journal of Tourism Research, 2(2), 119-131. 
Santana-Jiménez, Y., and Hernández, J. M. 2011. Estimating the effect of overcrowding on tourist attraction: The case of Canary Islands. Tourism Management, 32(2), 415-425.

Schofield, P. 1996. Cinematographic images of a city: Alternative heritage tourism in Manchester. Tourism Management, 17(5), 333-340.

Shackley, M. L. 1999. Visitor management. In A. Leask and I. Yeoman (eds.), Heritage Visitor Attractions: An Operations Management Perspective (pp. 6982). Cassells: London.

Shackley, M. L. 2009. Management challenges for religion-based attractions. In A. Fyall, B. Garrod, A. Leask and S. Wanhill (eds.), Managing Visitor Attractions: New Directions (pp. 253-263). Oxford: Butterworth-Heinemann.

Sheng, C. W., and Chen, M. C. 2012. A study of experience expectations of museum visitors. Tourism Management, 33(1), 53-60.

Smith, J. G. 1999. Learning from popular culture: Interpretation, visitors and critique. International Journal of Heritage Studies, 5, 135-148.

Smith, S. L. J. 2010. Practical Tourism Research. Wallingford, Oxfordshire, UK; Cambridge, MA: CAB International.

Stokowski, P. A. 1997. Constructing a sociological interpretation. Journal of Interpretation Research, 2(1), 47-53. 
Taheri, B., Jafari, A., and O'Gorman, K. 2014. Keeping your audience: Presenting a visitor engagement scale. Tourism Management, 42(10), 321-329.

Tongco, M. D. C. 2007. Purposive sampling as a tool for informant selection. Ethnobotany Research and Applications, 5, 147-158.

Timothy, D. J., and Boyd, S. W. 2003. Heritage Tourism. New York: Prentice Hall.

Timothy, D. J., and Boyd, S. W. 2006. Heritage tourism in the 21st century: Valued traditions and new perspectives. Journal of Heritage Tourism, 1(1), 1-16.

Tooke, N., and Baker, M. 1996. Seeing is believing: The effect of film on visitor numbers to screened locations. Tourism Management, 17(2), 87-94.

Tribe, J. 2005. New tourism research. Tourism Recreation Research, 30(2), 5-8.

Wang, Y., and Bramwell, B. 2012. Heritage protection and tourism development priorities in Hangzhou, China: A political economy and governance perspective. Tourism Management, 33(4), 988-998.

Watson, S., and McCracken, M. 2002. No attraction in strategic thinking: Perceptions on current and future skills needs for visitor attraction managers. International Journal of Tourism Research, 4(5), 367-378.

Wight, A., and Lennon, J. 2007. Selective interpretation and eclectic human heritage in Lithuania. Tourism Management, 28(2), 519-529.

Wilkes, K. and Richards, S., 2008. Attraction failure and success. In A. Fyall, B. Garrod., A. Leask and S. Wanhill., (eds.) Managing Visitor Attractions, (pp.3958). Oxford: Elsevier/Butterworth-Heinemann.

Winter, T. 2002. Angkor meets Tomb Raider: Setting the scene. International Journal of Heritage Studies, 8(4), 323-336. 
Wong, C. U. I., McIntosh, A., and Ryan, C. 2016. Visitor Management at a Buddhist Sacred Site. Journal of Travel Research, 55 (5), 675-687.

Yeh, S.-S., Aliana, L.-M. W., and Zhang, F.-Y. 2012. Visitors' perception of theme park crowding and behavioral consequences. Advances in Hospitality and Leisure, 8, 63-83.

Zhang, C., Fyall, A., and Zheng, Y. 2015. Heritage and tourism conflict within world heritage sites in China: A longitudinal study. Current Issues in Tourism, 18(2), 110-136.

Zimmermann, S. 2007. Media geographies - always part of the games. Aether - The Journal of Media Geography, 59-62. 